\title{
The Role of Domestic Demand in the Economic Growth of Cote d'Ivoire
}

\author{
Yaya Keho
}

\begin{abstract}
This study examines the relationship between domestic demand and economic growth in Cote d'Ivoire using time-series data over the period from 1970 to 2015 . The study uses two measures for domestic demand, namely household consumption and government consumption. The results show that household consumption and government consumption influence positively economic growth in the short and long-run. These findings suggest that domestic demand can be used as the catalyst for economic growth in Cote d'Ivoire.
\end{abstract}

Index Terms-Domestic demand, economic growth, cointegration, Cote d'Ivoire.

\section{INTRODUCTION}

The sources of economic growth have stimulated a growing body of theoretical and empirical literature. Mainstream growth models developed the idea that the source of economic growth is the availability of factors of production such as labor, technology and capital. In such framework, there is no fundamental role for demand since it is assumed that supply creates its own demand. In contrast to this framework, Keynesian models argued the principle of effective demand and, therefore, give emphasis to sources of aggregate demand. Hence, in Keynesian models growth is a demand-led process that is the economic growth rate is mostly influenced by growth of demand.

On the empirical front, the relationship between domestic demand and economic growth has yielded to mixed evidence. Some studies found that domestic demand causes economic growth (e.g. [1]), while others found that economic growth causes domestic demand (e.g. [2]). A bidirectional causal relationship has been found by [3] for Bahrain, Iran, Oman, Qatar, Saudi Arabia, Syria and Jordan, [4] for China, [5] for Ethiopia, and [6] for Bangladesh. As can be seen, there is very scanty evidence from African countries. The objective of this study is to provide insight on the growth impact of domestic demand in the context of Cote d'Ivoire using time series data covering the period 1970-2015. The study utilizes the ARDL bounds testing approach to cointegration to determine both the long run and short run impacts of domestic demand on economic growth.

The rest of the paper is organized as follows. Section II

Manuscript received July 16, 2018; revised September 7, 2018.

Yaya Keho is with Ecole Nationale Supérieure de Statistique et d'Economie Appliquée (ENSEA), Abidjan, Cote d'Ivoire (e-mail: yayakeho@yahoo.fr). outlines the econometric methodology of the study. Section III describes the data used in the empirical analysis. Section IV discusses the empirical results and Section $\mathrm{V}$ concludes the study and provides some policy recommendations.

\section{DATA AND MethodologY}

\section{A. Data and Model}

The study uses annual data on real GDP, household consumption, government consumption in constant local currency, and labor. All data are converted into natural logarithms. The data set comes from the World Development Indicators and covers the period 1970-2015. The empirical model is specified as follows:

$$
\ln G D P_{t}=\theta_{0}+\theta_{1} \ln H C_{t}+\theta_{2} \ln G C_{t}+\theta_{3} \ln L_{t}+\mu_{t}
$$

where $G D P$ represents real $G D P, H C$ is real household final consumption, GC is real government final consumption, and $L$ is population.

TABLE I: DESCRIPTIVE STATISTICS AND CORRELATION MATRIX

\begin{tabular}{|c|c|c|c|c|}
\hline Variables & $\operatorname{lnGDP}$ & $\ln \mathrm{HC}$ & $\operatorname{lnGC}$ & $\ln L$ \\
\hline \multicolumn{5}{|c|}{ Panel A: Summary statistics } \\
\hline Mean & 29.814 & 24.782 & 23.306 & 16.322 \\
\hline Median & 29.769 & 24.727 & 23.357 & 16.401 \\
\hline Maximum & 30.398 & 25.425 & 23.953 & 16.937 \\
\hline Minimum & 29.167 & 24.071 & 22.631 & 15.472 \\
\hline Std. dev. & 0.263 & 0.291 & 0.234 & 0.435 \\
\hline Skewness & -0.328 & -0.167 & -0.230 & -0.401 \\
\hline Kurtosis & 3.199 & 3.011 & 4.297 & 1.931 \\
\hline Jarque-Bera & 0.903 & 0.214 & 3.630 & 3.422 \\
\hline Probability & 0.636 & 0.898 & 0.162 & 0.180 \\
\hline \multicolumn{5}{|c|}{ Panel B: Correlation matrix } \\
\hline $\operatorname{lnGDP}$ & 1.000 & & & \\
\hline $\ln \mathrm{HC}$ & 0.983 & 1.000 & & \\
\hline $\operatorname{lnGC}$ & 0.786 & 0.803 & 1.000 & \\
\hline $\ln \mathrm{L}$ & 0.934 & 0.922 & 0.578 & 1.000 \\
\hline
\end{tabular}

Table I provides descriptive statistics and correlations of the variables. It can be observed that log of real GDP per capita has an average level of 29.814, while household consumption in log averaged 24.782 and government consumption averaged 23.306. These figures indicate that the share of household consumption in GDP is greater than that of government consumption. More precisely, household consumption accounts for $64.5 \%$ to GDP while government consumption contributes to GDP by $14.8 \%$. The correlation matrix indicates positive relationships between the variables. However, correlation does not mean causality. A positive 
correlation between domestic demand and GDP can be compatible with the demand-led growth hypothesis, the growth-led demand hypothesis or a two-way causality between domestic demand and economic growth.

\section{B. Econometric Methodology}

The empirical estimation involves three steps. Firstly, unit root tests are employed to examine the stationarity of the variables. Secondly, we examine the presence of long-run relationships between the variables. Thirdly, we carry out causal relationships among the variables using Granger causality tests. The Autoregressive Distributed Lag (ARDL) bounds testing approach to cointegration developed by [7] is used to depict the long run relationship among the variables. The advantages of this approach over other traditional alternative methods have been documented in the econometric literature. It has been shown to have superior properties in small sample size. The ARDL bounds testing approach to cointegration is based on the following error-correction model:

$$
\begin{aligned}
& \Delta y_{t}=\phi_{0}+\phi_{1} y_{t-1}+\phi_{2} h c_{t-1}+\phi_{3} g c_{t-1}+\phi_{4} l_{t}+\sum_{i=1}^{m} \gamma_{1 i} \Delta y_{t-i}+ \\
& \sum_{i=0}^{n} \gamma_{2 i} \Delta h c_{t-i}+\sum_{i=0}^{p} \gamma_{3 i} \Delta g c_{t-i}+\sum_{i=0}^{q} \gamma_{4 i} \Delta l_{t-i}+e_{t}
\end{aligned}
$$

where $\Delta$ is the difference operator, $y, h c, g c$, and $l$ are the $\log$ of real GDP, household consumption, government consumption, and population, respectively. "Equation (2)" is estimated using each variable as the dependent variable. The presence of long-run relationship is tested by restricting coefficients of lagged level variables equal to zero. That is, the null hypothesis of no long-run relationship is: $\varphi_{1}=\varphi_{2}=\varphi_{3}=\varphi_{4}=0$. This hypothesis is tested by the mean of an $F$-test. The bounds testing procedure is sensitive to the selection of the lag structure $(m, n, p)$. In this study, maximum lag length on each variable was set to five and the optimal lag structure was selected using the Akaike Information Criterion (AIC). The model has been tested by the diagnostic tests that are serial correlation, normality and heteroskedasticity tests. Stability tests have also been used to test the goodness of fit of the ARDL model. If there is a long run relationship among the variables then the long run estimates are computed as: $\theta_{i}=-\varphi_{i} / \varphi_{1}$.
The cointegration analysis indicates whether or not a long run relationship exists between the variables, but not the direction of causality. To investigate the direction of causal relationships among the variables, we apply Granger causality tests. We estimate the following model:

$$
\begin{aligned}
& (1-L)\left[\begin{array}{l}
y_{t} \\
h c_{t} \\
g c_{t} \\
l_{t}
\end{array}\right]=\left(\begin{array}{l}
\alpha_{1} \\
\alpha_{2} \\
\alpha_{3} \\
\alpha_{4}
\end{array}\right)+\sum_{i=1}^{p}(1-L)\left(\begin{array}{lll}
\beta_{1 i} & \gamma_{1 i} & \varphi_{1 i} \\
\beta_{2 i} & \gamma_{2 i} & \varphi_{2 i} \\
\beta_{3 i} & \gamma_{3 i} & \varphi_{3 i} \\
\beta_{4 i} & \gamma_{4 i} & \varphi_{4 i}
\end{array}\right) \times\left[\begin{array}{l}
y_{t-i} \\
h c_{t-i} \\
g c_{t-i} \\
l_{t-i}
\end{array}\right]+ \\
& \left(\begin{array}{l}
\lambda_{1} \\
\lambda_{2} \\
\lambda_{3} \\
\lambda_{4}
\end{array}\right) E C T_{t-1}+\left[\begin{array}{l}
e_{1 t} \\
e_{2 t} \\
e_{3 t} \\
e_{4 t}
\end{array}\right]
\end{aligned}
$$

where $(1-L)$ stands for the difference operator, and $\mathrm{ECT}_{t-1}$ denotes the lagged residuals of the long-run relationship. The lag length $p$ is determined using the AIC criterion. The significance of the differenced explanatory variables indicates the short-run causality whereas the significance of $\mathrm{ECT}_{t-1}$ suggests the long-run causal relationship. For instance, the null hypothesis that household consumption does not cause GDP in short run is $\gamma_{11}=\gamma_{12}=\ldots=\gamma_{1 p}=0$.

\section{EMPIRICAL RESULTS AND DISCUSSION}

\begin{tabular}{lccccc}
\multicolumn{3}{c}{ TABLE II: RESULTS OF UNIT RoOT TESTS } \\
\hline \multirow{2}{*}{ Series } & Level & & & \multicolumn{2}{c}{ First difference } \\
\cline { 2 - 3 } \cline { 5 - 6 } \cline { 5 - 6 } & PP & KPSS & & PP & KPSS \\
\hline $\operatorname{lnGDP}$ & -2.618 & 0.083 & & $-4.320^{*}$ & 0.138 \\
$\ln H C$ & -2.551 & 0.084 & & $-5.273^{*}$ & 0.152 \\
$\operatorname{lnGC}$ & -2.668 & 0.107 & & $-7.209^{*}$ & 0.157 \\
$\operatorname{lnL}$ & -1.384 & $0.228^{*}$ & & -1.057 & 0.109 \\
\hline
\end{tabular}

Note: $\mathrm{HC}=$ household consumption, $\mathrm{GC}=$ government consumption, $\mathrm{L}=$ population. *(**) denotes the rejection of the null hypothesis at the $5 \%(10 \%)$ level.

We test for the order of integration of the variables using the PP test of [8] and the KPSS test of [9]. This step is necessary because the ARDL bounds test requires the dependent variable to be integrated of order one. The results displayed in Table II suggest that the variables are

\begin{tabular}{|c|c|c|c|c|c|}
\hline \multirow{2}{*}{ Dep. var. } & \multirow[t]{2}{*}{ ARDL } & \multirow[t]{2}{*}{ F_stat. } & Diagnostic tests & \multirow[b]{2}{*}{$\chi^{2}$ (Heteroscedasticity) } & \multirow[b]{2}{*}{$\chi^{2}$ (Correlation) } \\
\hline & & & $x^{2}$ (Normality) & & \\
\hline $\operatorname{lnGDP}$ & $\operatorname{ARDL}(4,0,0,1)$ & $5.226^{*}$ & 0.133 & 0.214 & 0.546 \\
\hline $\ln \mathrm{HC}$ & $\operatorname{ARDL}(1,1,0,0)$ & 1.271 & 0.730 & 0.331 & 0.722 \\
\hline \multirow[t]{3}{*}{$\operatorname{lnGC}$} & $\operatorname{ARDL}(1,2,1,0)$ & $7.255^{*}$ & 0.526 & 0.238 & 0.695 \\
\hline & \multicolumn{3}{|c|}{ Critical values $(T=46)$} & & \\
\hline & Lower bounds I & & Upper bounds I(1) & & \\
\hline $5 \%$ & 3.23 & & 4.35 & & \\
\hline $10 \%$ & 2.72 & & 3.77 & & \\
\hline
\end{tabular}
non-stationary in their level but become stationary after differencing.

TABLE III: RESULTS OF THE ARDL COINTEGRATION TEST

Note: $\mathrm{HC}=$ household consumption, GC=government consumption, $\mathrm{L}=$ population. Lag length on each variable is selected using the AIC criterion with maximum lag set to 5. To control for stability a dummy variable was included taking value 1 over 1988-2006, and 0 otherwise. Critical values are [7] for the model with unrestricted intercept and no trend. * indicates the rejection of the null hypothesis of no cointegration at $5 \%$ level of significance. 
TABLE IV: LONG RUN ESTIMATES

\begin{tabular}{lllllll}
\hline Var. & \multicolumn{6}{l}{ Dependent variable: lnGDP } \\
\cline { 2 - 7 } & ARDL & \multicolumn{3}{l}{ FMOLS } & & DOLS \\
\cline { 2 - 7 } & Coef. & t-stat. & Coef. & t-stat. & Coef. & t-stat. \\
\hline $\operatorname{lnHC}$ & $0.573^{*}$ & 4.850 & $0.463^{*}$ & 2.731 & $0.509^{*}$ & 2.547 \\
$\operatorname{lnGC}$ & $0.121^{*}$ & 2.202 & $0.179^{* *}$ & 1.754 & 0.134 & 1.091 \\
$\operatorname{lnL}$ & $0.315^{*}$ & 4.465 & $0.223^{*}$ & 2.692 & $0.330^{*}$ & 2.835 \\
Cons & $7.366^{*}$ & 4.411 & $10.499^{*}$ & 7.296 & $8.483^{*}$ & 5.081 \\
\hline
\end{tabular}

Note: $\mathrm{HC}=$ household consumption, $\mathrm{GC}=$ government consumption, $\mathrm{L}=$ population. The asterisks $*$ and $* *$ denote statistical significance at the $5 \%$ and $10 \%$ levels, respectively.

Given the above results, we further estimate the long run relationship between the variables. We estimate the long run coefficients using ARDL, Fully Modified OLS and Dynamic OLS methods. The results are presented in Table IV. The estimated coefficients on household consumption and labor are highly significant and have correct signs as expected. A $1 \%$ increase in household consumption leads to about $0.6 \%$ increase in real GDP. Furthermore, government consumption is positively and significantly related to economic growth with an elasticity of $0.12 \%$. The estimates from FMOLS and DOLS show similar results. Overall, our findings support the demand-led growth hypothesis in the long-run. This implies that domestic expenditure can be used as the catalyst for long-run economic growth in Cote d'Ivoire.

The short run dynamics results are reported in Table V. The coefficient on the lagged error correction term is significant with the correct sign, supporting the evidence of a long-run relationship among the variables. The elasticity of output with respect to household consumption or government consumption is positive and statistically significant. Therefore, in the short-run, household consumption and government consumption contribute positively to economic growth in Cote d'Ivoire.

TABLE V: SHORT RUN ESTIMATION RESULTS

\begin{tabular}{|c|c|c|c|}
\hline \multirow[t]{2}{*}{ Regressor } & \multicolumn{3}{|c|}{$\begin{array}{l}\text { Dependent variable: } \\
\Delta \ln (\text { GDP })\end{array}$} \\
\hline & Coef. & t-stat. & Prob. \\
\hline$\Delta \ln \mathrm{HC}$ & $0.460^{*}$ & 4.352 & 0.000 \\
\hline$\Delta \ln G C$ & $0.159^{*}$ & 3.645 & 0.001 \\
\hline$\Delta \ln L$ & $3.683^{*}$ & 3.159 & 0.003 \\
\hline Constant & $3.220^{*}$ & 3.113 & 0.003 \\
\hline $\operatorname{ECM}(-1)$ & $-0.438^{*}$ & -3.117 & 0.004 \\
\hline
\end{tabular}

Note: $\mathrm{HC}=$ household consumption, $\mathrm{GC}=$ government consumption, $\mathrm{L}=$ population. The asterisks * denotes statistical significance at the $5 \%$ level.

TABLE VI: RESULTS OF GRANGER CAUSALITY TESTS

\begin{tabular}{llllll}
\hline \multirow{2}{*}{$\begin{array}{l}\text { Dep. } \\
\text { var. }\end{array}$} & \multicolumn{5}{c}{ Causal variable } \\
\cline { 2 - 6 } & $\operatorname{lnGDP}$ & $\ln \mathrm{HC}$ & $\operatorname{lnGC}$ & $\operatorname{lnL}$ & ECT \\
\hline $\ln \mathrm{nDP}$ & - & 0.368 & 0.202 & $0.001^{*}$ & $-3.818^{*}$ \\
$\ln \mathrm{HC}$ & 0.907 & - & 0.666 & 0.252 & -0.429 \\
$\operatorname{lnGC}$ & 0.973 & 0.839 & - & 0.397 & -1.043 \\
\hline
\end{tabular}

Note: $\mathrm{HC}=$ household consumption, $\mathrm{GC}=$ government consumption, $\mathrm{L}=$ population. Figures reported are p-values of Wald statistics and those for ECT are t-statistics. * (**) indicates significance at the 5\% (10\%) level.

The results of the Granger-causality tests are displayed in Table VI. The point estimates of the error correction terms show that in the long-run both household consumption and government consumption Granger-cause economic growth. This evidence is in line with the view that domestic demand leads to economic growth. With respect to the short-run causality, labor was found to cause economic growth. This confirms the role of population growth in economic growth. The absence of Granger causality running from economic growth to explanatory variables suggests exogeneity of these variables.

\section{CONCLUSION}

This paper has examined the impact of domestic demand on economic growth in Cote d'Ivoire over the period 1970-2015. It uses two measures for domestic demand, namely household consumption and government consumption. The study employed the ARDL approach that is more reliable in studies involving relatively shorter sample sizes. The results show that household consumption and government consumption are playing a significant role in the economic growth of Cote d'Ivoire both in the short and long-run. Furthermore, Granger causality tests were carried out to determine the direction of causality among the variables. Both household consumption and government consumption were found to cause economic growth in the long-run. Our results validate the demand-led growth hypothesis for Cote d'Ivoire over the period 1970-2015.

These findings imply that household and government consumption can be used as the catalyst for economic growth in Cote d'Ivoire. Cote d'Ivoire has an aspiration to achieve a status of an emerging country by 2020 , provided that the country can grow between 6 to 7 percent per year. Due to external factors and uncertainties in the global economic conditions, Cote d'Ivoire should highly depend on the domestic economy as the main source of economic growth during the period from 2016-2020.

\section{REFERENCES}

[1] L. Y. Wah, "The role of domestic demand in the economic growth of Malaysia: a cointegration analysis," International Economic Journal, vol. 18, no. 3, pp. 337-352, February 2010.

[2] O. P. Chimobi and U. C. Uche, "Export, domestic demand and economic growth in Nigeria: Granger causality analysis," European Journal of Social Sciences, vol. 13, no. 2, pp. 211-218, March 2010.

[3] W. H. Tsen, "Exports, domestic demand and economic growth: Some empirical evidence of the middle east countries," Journal of Economic Cooperation, vol. 28, no. 2, pp. 57-82, 2007.

[4] W. H. Tsen, "Exports, domestic demand, and economic growth in China: Granger causality analysis," Review of Development Economics, vol. 14, no. 3, pp. 625-639, August 2010. 
[5] S. T. Jarra, "Exports, domestic demand and economic growth in Ethiopia: A Granger causality analysis," Journal of Economics and International Finance, vol. 5, no. 9, pp. 357-372, December 2013.

[6] M. K. Islam and M. E. Hossain, "Domestic demand, export and economic growth in Bangladesh: A cointegration and VECM approach," Economics, vol. 4, no. 1, pp. 1-10, February 2015.

[7] H. Pesaran, Y. Shin, and R. J. Smith, "Bounds testing approaches to the analysis of level relationships," Journal of Applied Econometrics. vol. 16, no. 3, pp. 289-326, June 2001.

[8] P. C. B. Phillips and P. Perron, "Testing for a unit root in a time series regression," Biometrika, vol. 75, no. 2, pp. 335-346, June 1988.

[9] D. Kwiatkowski, P. C. B. Phillips, P. Schmidt, and Y. Shin, "Testing the null hypothesis of stationarity against the alternative of a unit root," Journal of Econometrics, vol. 54, no. 1-3, pp. 159-178, October-December 1992.

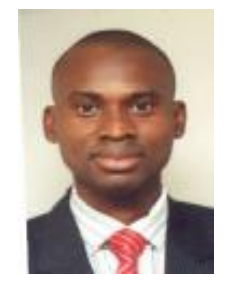

Yaya Keho was born in Cote d'Ivoire on December 12,1973 . He is working as a professor of econometrics and statistics at the National School of Statistics and Applied Economics (ENSEA) of Abidjan, Côte d'Ivoire. He earned his Ph.D. in economic development from the University of Saint Quentin-en-Yveline, at France in 2006.

He has published in many international revues including South African Journal of Economics, The Journal of Energy and Development, International Economic Journal, African Finance Journal, Journal of African Studies and Development, Asian Economic and Financial Review, International Journal of Economics.

His research interests focus on public finance, energy, financial development and applied econometrics. 